\title{
The Effect of Environmental Commitment on Financial Performance through Green Innovation
}

\author{
${\text { Movie Rahmatika Suryani }{ }^{1 *} \text {, Wiwiek Dianawati }}^{2}$ \\ Airlangga University, Indonesia
}

*Corresponding Author: Movie Rahmatika Suryani, Airlangga University, Indonesia

\begin{abstract}
The main objective of this research is to demonstrate empirically the effect of environmental commitment on financial performance through green innovation in the manufacturing companies listed in Indonesia Stock Exchange (IDX). This research was conducted by examining the effect of environmental commitment that refer to ISO 14001 as a independent variable on financial performance of the company that using return on equity (ROE) as a dependent variable through green process innovation and green product innovation as a mediating variable.
\end{abstract}

Samples were taken from the financial statements companies listed in Indonesia Stock Exchange (IDX) in 2014-2016. The sample was selected using sensus sampling method and acquired 202 companies. Using SPSS version 20 with the method of path analysis completed by hierarchial regression analysis with a significance level of $5 \%$ specified.

The results of this study show that environmental commitment have positive and significant effect on financial performance mediated by green process innovation, but green product innovation has not succeeded in mediating the effect of environmental commitment on financial performance.

Keywords: Environmental Commitment, Green Process Innovation, Green Product Innovation, Financial Performance

\section{INTRODUCTION}

The issue of environmental pollution in the industrial is main concern to parties in Indonesia. The Ministry of Industry of the Republic of Indonesia also explained through a presentation by Munandar (2017: 161) that the global consumption trend for 40 years towards resources has increased by 3 times from 1970 as much as 20 billion tons, then for 2010 it increased to 70 billion tons and 2050 is predicted to increase by 180 billion if there is no lifestyle change.

The Government of Indonesia through the National Development Planning Agency (BAPPENAS) prepared a National Medium Term Development Plan (RPJMN) with the theme "green" as a form of commitment in promoting sustainable development in Indonesia by placing the environment and natural resources as the main development concerns. This is because Indonesia has become an important country in the Masyarakat Ekonomi Asean (MEA) which allows foreign companies to market their products and services in Indonesia and make it easier for foreign investors to invest in Indonesia. Based on this phenomenon, the Indonesian government must have a strategy to increase industrial competitiveness by being open to international issues. One international issue that has received attention today is the existence of a green industry (Atmawinata, 2012). Green industries support environmentally friendly industries, companies must be able to prevent large environmental damage from production activities by creating an environment-based innovation. This is known as green innovation.

In implementing the practice of green innovation, companies must be supported by a company commitment to the environment. The existence of environmental commitment is a source of support for companies to adopt new environmental programs and to improve the company's environmental strategy (Sarkis et al., 2010). According to Suasana and Ekawati (2018) and Chang and Chen (2013) show that the higher the company's commitment to safeguard the environment in its business activities, the better the application of green process innovation and green product innovation in the company. 
The application of green process innovation and green product innovation in companies can increase competitiveness for companies. Green process innovation creates environmental friendliness through effective production processes by using raw materials and energy efficiently so as to reduce production costs. Reducing production costs can provide benefits for companies to increase profits that can provide an increase in financial performance (Kucukoglu and Pinar, 2015). The results of research by Alhadid and Rumman (2014) also provide empirical evidence that green process innovation has an influence on improving financial performance. The existence of green product innovation is a unique tool for marketing activities because of the increasing market share of the company (Kucukoglu and Pinar, 2015). In addition, the company also has a cost-leadership strategy. Increased market share and cost-leadership strategies have an impact on increasing corporate profits that can achieve better financial performance (Sudaryati and Amelia, 2015).

Better financial performance is also carried out through cost-leadership strategies and product differentiation strategies which are the result of the application of green product innovation in the company (Caracuel and Mandojana, 2013). In accordance with research conducted by Ar (2012) and Miroshnychenko et al. (2017) provides empirical evidence that the company's green product innovation can improve financial performance.

Therefore, green innovation which consists of green process innovation and green product innovation in this research plays a role in mediating the influence of environmental commitment on the company's financial performance. Research conducted by Ryszko (2016) provides empirical evidence that green process innovation and green product innovation can mediate the influence of environmental commitment on financial performance. Research by Grekova et al. (2013) also shows empirical evidence that green process innovation has succeeded in mediating the influence of environmental commitment on financial performance, but green product innovation has not proven to mediate this relationship.

Caracuel and Mandojana's (2013) research provides the opposite results. The existence of green innovation cannot run optimally because of knowledge gaps, unwillingness to take risks in the market, and inadequate government support. Chang (2011) and Fitriani (2017) also provide empirical evidence that innovation does not directly benefit the company because it requires a long time so that innovation can be beneficial to the company's performance.

Based on the explanation previously described and the research gap or inconsistency of results in previous studies, it is important to research further about the influence of environmental commitment, green process innovation, green product innovation and its impact on financial performance in Indonesia, considering that Indonesia is a developing country. In addition, a few previous studies have also examined this topic, especially in Indonesia.

\section{THEORY FOUNDATION AND DEVELOPMENT OF HYPOTHESES}

\subsection{Institutional Theory}

DiMaggio and Powell (1983) describe Institutional Theory based on the assumption that the environment requires companies in two different ways. First, demands are technical or economic so that the organization must be efficient and effective in producing and supplying goods and services. Second, demands that constitute social and cultural legitimacy of the community so that the organization must be in accordance with the values, norms, rules and beliefs held by the community. Organizational adaptation is not only internal efficiency, but conformity with values in society.

\subsection{Legitimacy Theory}

Deegan (2002) defines Legitimacy Theory as a condition in which the value system applied by an entity is in line with the broader community value system. If the company has communicated with the community so that it knows the true hope of the community. Furthermore, the company managed to build this perception and implement an environmentally friendly innovation strategy that is good, so that the company has succeeded in gaining legitimacy. With the company's commitment to the environment and green innovation, companies are easier to get legitimacy from the community.

\subsection{Effect of Environmental Commitments on Financial Performance}

Environmental commitment has a very important role in achieving financial performance. Based on Legitimacy Theory focuses on the interaction between the company and society (Aziza, 2014). To 
gain legitimacy, companies really take proactive environmental actions that are reflected in the company's commitment to the environment (Henriques and Sadorsky, 1999).

Environmental commitment can attract public sympathy, resulting in increased public attitudes towards the company (Agustina and Fauzi, 2016). By meeting the expectations of stakeholders proactively and aligning them with the company's commitment to the environment, the company will experience improved performance (Menguc and Ozanne, 2005).

This is supported by research by Ozzie and Malelak (2015), Cui et al. (2015), Yahya and Ha (2013), Azorín et al. (2009), Benito and Benito (2005), and Menguc and Ozanne (2005) that the application of environmental commitments in companies can be proven to improve financial performance. Based on the description above, the following hypothesis is formulated:

\section{H1: Environmental commitment has a positive effect on financial performance.}

\subsection{Effect of Environmental Commitment on Green Process Innovation}

It is based on institutional theory, where the social environment demands the company to two different ways. First, encourage companies to be efficient and effective in producing and supplying goods and services. Secondly, encouraging companies to be in accordance with the values, norms, rules and beliefs held by the community.

Companies that need to develop a commitment. The company's commitment can effectively stimulate the practice of green innovation in the company (Burki and Dahlstrom, 2017). According to Atmosphere and Ekawati (2018) the higher the company's commitment to safeguarding the environment in its business activities, the better the application of green process innovation. The existence of green process innovation encourages efficient and effective companies in producing and supplying goods and services and encouraging companies in accordance with the values, norms, rules, and beliefs adopted by the community. Where the values are embraced by the community is the protection of the ecosystem in the long run.

The same thing was also revealed in the study of Burki and Dahlstrom (2017), Richey et al. (2005), and Chang and Chen (2013) that a company's environmental commitment can affect green process innovation. But it is not in line with the research conducted by Caracuel and Mandojana (2013) explaining that environmental innovation is not running optimally because of knowledge gaps, unwillingness to take risks in the capital market, and inadequate government support. Based on the description above, the following hypothesis is formulated:

\section{H2: Environmental Commitment affects Green Process Innovation}

\subsection{Effect of Environmental Commitment on Green Product Innovation}

Based on Legitimacy Theory, encouraging social value in a company must be in accordance with the values, norms, rules and beliefs held by the community. Therefore, the company needs to develop a commitment to support companies to make environmentally friendly innovations. Commitment encourages the fulfillment of the expectations of stakeholders so that it can encourage the practice of green innovation more optimally in the company

Companies with a high commitment to the environment influence the achievement of green process innovation in the company because of the pressure from stakeholders to care for the environment (Kassar and Singh, 2018). The application of green product innovation is done by redesigning products to be environmentally friendly, modifying product components and intervening after the sales process to reduce the amount of waste and packaging for customers is called green product innovation.

The same thing was expressed in the research of Atmosphere and Ekawati (2018), Burki and Dahlstrom (2017), and Chang and Chen (2013) that environmental commitment of a company can affect green product innovation. But it is not in line with the research conducted by Wagner (2008) environmental commitment has no significant effect on green product innovation. Based on the description above, the following hypothesis is formulated:

\section{H3: Environmental Commitment has an effect on Green Product Innovation}

\subsection{Effect of Green Process Innovation on Financial Performance}

Green process innovation builds environmental friendliness and effective production processes by using raw materials and energy efficiently (Kucukoglu and P1nar, 2015). The efficient use of raw 
materials and energy will have an impact on reducing production costs. Reducing production costs will provide benefits for companies to increase profits generated due to low production costs. increasing the practice of green process innovation has an impact on improving financial performance as well.

This is consistent with research conducted by Fitriani (2017), Alhadid and Rumman (2014), and Chang and Chen (2013) which provide empirical evidence that green process innovation can affect financial performance. But it is not in line with research conducted by Chang (2011) and Gunday et al. (2011) provide empirical evidence that companies that do innovation do not directly benefit the company's financial performance. Based on the description above, the following hypothesis is formulated:

\section{H4: Green Process Innovation affects financial performance}

\subsection{Effect of Green Product Innovation on Financial Performance}

Green product innovation has an important role in improving the company's financial performance. Kucukoglu and Pinar (2015) added the existence of green product innovation as a unique tool for marketing activities by increasing market share continuously. In addition, there is a cost leadership strategy. This has an impact on increasing corporate profits (Sudaryati and Amelia, 2015).

Chen et al. (2012) explained that green product innovation is an advantage for companies to conduct differentiation strategies. Companies that pioneered green product innovation can gain competitive advantage, and enable them to sell environmentally friendly products, to improve their company's reputation, and to create new markets (Chen et al., 2006).

Results of research by Kucukoglu and Pınar (2015), Ar (2012), Miroshnychenko et.al (2017), Chang and Chen (2013) and Tang et al. (2018) provides empirical evidence that the application of green product innovation can affect the company's financial performance. But not in line with the research conducted by Caracuel and Mandojana (2013) and Fitriani (2017) which provides green product innovation does not have a significant effect on financial performance. Based on the description above, the following hypothesis is formulated:

\section{H5: Green Product Innovation affects financial performance}

\subsection{Effect of Environmental Commitment on Financial Performance through Green Process Innovation}

According to research by Grekova et al. (2013), the existence of green process innovation can mediate the influence of environmental commitment on financial performance. This is because the optimal application of green process innovation must be supported by the company's commitment to care for the environment or what is called environmental commitment. The commitment shows the respect of companies that will encourage companies to innovate environmentally friendly processes. Environmentally friendly process innovation, companies can minimize production waste and improve resource efficiency (Chang, 2011). This can increase productivity and efficiency in the company so that it has an impact on financial performance.

Therefore, green process innovation plays an important role in mediating the influence of environmental commitment on the company's financial performance. This is consistent with research conducted by Ryszko (2016), Burki and Dahlstrom (2017) and Grekova et al. (2013) which shows that green process innovation is a mediating variable. Therefore, the hypothesis formulated:

\section{H6: Environmental Commitment influences Financial Performance through Green Process Innovation}

\subsection{Pengaruh Environmental Commitment Terhadap Kinerja Keuangan Melalui Green Product Innovation}

According to Grekova et al. (2013), the existence of green product innovation can mediate the influence of environmental commitment on financial performance. This is because the optimal application of green product innovation must be supported by the company's commitment to care for the environment or what is called environmental commitment. When a company carries out an environmental strategy in the form of commitment can result in an increase in public attitudes towards the company (Agustina and Fauzi, 2016). With the increasing public attitude towards the company, it 
can encourage better financial performance because these environmentally friendly products are attractive to consumers or customers who care about the environment so that it increases sales that will provide better financial performance.

In addition, green product innovation can increase market share and make companies have cost leadership strategies and differentiation strategies. Therefore, green product innovation plays an important role in mediating the influence of environmental commitment on the company's financial performance. This is consistent with research conducted by Ryszko (2016) and Burki and Dahlstrom (2017) which show that green product innovation is a mediating variable. But it is not in line with research conducted by Grekova et al. (2013) and Aznar et al. (2016) where green product innovation cannot be a link between the influence of environmental commitment on financial performance. Therefore, the hypothesis formulated:

\section{H7: Environmental Commitment influences Financial Performance through Green Product Innovation}

\section{RESEARCH METHODS}

The study uses a quantitative approach that aims to prove the hypothesis that has been proposed through path analysis (path analysis) with stepwise regression analysis with SPSS 20 software to help the author in the data processing process.

The study population uses 435 manufacturing companies that have been listed on the Indonesia Stock Exchange (IDX) with the 2014-2016 period. Using the sampling census method, 202 companies were obtained.

\section{OPERATIONAL DEFINITION}

\subsection{Environmental Commitment}

In this study, environmental commitment is an independent variable. Environmental commitment measurement refers to research conducted by Nishitani (2009) using ISO 140001 as a proxy for environmental commitment variables in companies with dummy variables, where the number 1 (one) shows companies that already have ISO 14001 certification and the number 0 (zero) indicates the do not have ISO 14001 certification.

\subsection{Financial Performance}

In this study, financial performance as a dependent variable. Using ROE as a measurement of financial performance is calculated using the following formula.

Return on Equity $=\frac{\text { Profit After Tax }}{\text { Total Equity }} \times 100 \%$

\subsection{Green Process Innovation}

In this study, green process innovation is a mediating variable. Measurement uses the approach taken by Peters (2005) with the following formula:

Green Process Innovation =

$\frac{\text { (Energy Costs it }+ \text { Raw Material Costs it) }-(\text { Energy Costs it }-1+\text { Raw Material Costs it }-1)}{\text { Sales (it }-1)}$

\subsection{Green Product Innovation}

In this study, green product innovation is a mediating variable. Measurement uses the approach taken by Peters (2005) with the following formula:

Green Product Innovation $=\frac{\text { Net Cash flow operation It }- \text { Net Cash Flow Operation (It-1) }}{\text { Sales (It-1) }}$

\subsection{Debt to Equity Ratio}

In this study, debt to equity ratio (DER) was the control variable. According Sudana (2009: 23) debt to equity ratio is formulated as follows:

$D E R=\frac{\text { Total Liabilities }}{\text { Total Equity }}$ 


\subsection{Firm Size}

In this study, firm size (SIZE) as a control variable. According to Miroshnychenko et al. (2017) formulated as follows:

SIZE $=$ Log (total asset)

\subsection{Data Analysis Technique}

This study uses path analysis techniques (path analysis) with stepwise regression analysis using SPSS 20. Before doing regression analysis several steps and analysis tools are needed. First do the descriptive statistical method. Secondly, the classical assumption (normality, multicollinearity, and heteroscedasticity) was tested and the hypothesis was tested.

\subsection{Path Analysis Model}

To test the direct influence of the environmental variable on the dependent variable (financial performance) in this study using several regression models, among others:

Regression Model 1 :

PROCESS $=\beta_{1}$ ISO $+\beta_{2}$ DER $+\beta_{3}$ SIZE $+e$

Regression Model 2 :

PRODUCT $=\beta_{4}$ ISO $+\beta_{5}$ DER $+\beta_{6}$ SIZE $+e$

Regression Model 3 :

\section{ROE $=\beta_{7}$ ISO $+\beta_{8}$ PRODUCT $+\beta_{9}$ PROCESS $+\beta_{10}$ DER $+\beta_{11}$ SIZE $+e$}

Information :

$\begin{array}{ll}\text { PRODUCT } & =\text { Green Product Innovation } \\ \text { PROCESS } & =\text { Green Process Innovation } \\ \text { ISO } & =\text { ISO } 14001 \text { (environmental commitment) } \\ \text { ROE } & =\text { Return on Equity (Financial Performance) } \\ \beta_{1-} \beta_{11} & =\text { Regression Coefficients } \\ \text { DER } & =\text { Debt to Equity Ratio } \\ \text { SIZE } & =\text { Size Company }\end{array}$

\section{HyPOTHESIS TESTING}

\subsection{Direct Influence Testing}

To test the direct effect of the independent variable (environmental commitment) on the dependent variable (financial performance) in this study using the $t$ test.

\subsection{Indirect Influence Testing}

Testing the indirect effect of the independent variable $(\mathrm{X})$ on the dependent variable $(\mathrm{Y})$ through the mediating variable $(Z)$ in this study can be done by testing developed by Sobel (1982) known as sobel (sobel test).

\section{RESULTS AND DisCUSSION}

\subsection{Descriptive Statistics Results}

Table2. Descriptive statistics

\begin{tabular}{|l|c|l|l|l|l|}
\hline & \multicolumn{1}{|c|}{ Minimum } & \multicolumn{1}{c|}{ Maximum } & \multicolumn{1}{c|}{ Mean } & \multicolumn{1}{c|}{ Std. Deviation } \\
\hline ROE & 202 & -.333966 & .367504 & .05261674 & .105759514 \\
\hline PROCESS & 202 & -.402919 & .297640 & -.01294467 & .118994121 \\
\hline PRODUCT & 202 & -.297911 & .430251 & .00854778 & .103390256 \\
\hline ISO & 202 & 0 & 1 & .50 & .501 \\
\hline DER & 202 & -1.947166 & 5.390170 & 1.04081940 & 1.039807560 \\
\hline SIZE & 202 & 10.602934 & 13.965783 & 12.32147148 & .653048312 \\
\hline
\end{tabular}




\subsection{Classical Assumption Test Results}

Table3. Normality Test Results

\begin{tabular}{|l|l|l|l|l|}
\hline Model & \multicolumn{1}{|c|}{$\mathbf{N}$} & \multicolumn{1}{|c|}{ Kolmogorov-Smirnov Z } & \multicolumn{1}{|c|}{ Asymp. Sig. (2-tailed) } & Conclusion \\
\hline 1 & 202 & 1.043 & 0.226 & Normal \\
\hline 2 & 202 & 1.207 & 0.108 & Normal \\
\hline 3 & 202 & 0.586 & 0.882 & Normal \\
\hline
\end{tabular}

Source: processed data, 2018

These results indicate that the regression model 1, regression model 2, and regression model 3 built in this study have data that is normally distributed because of the value asymp. Sig (2-tailed) $>0,05$.

Table4. Multicollinearity Test Results

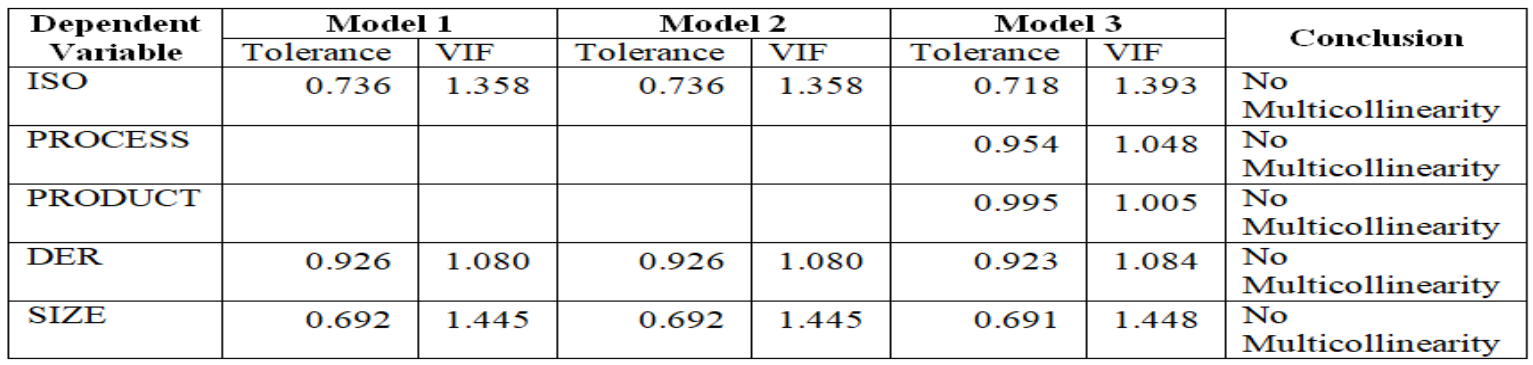

Source: processed data, 2018

The multicollinearity test results in table 4 show that the regression model 1 , regression model 2 , and regression model 3 that was built in this study did not experience multicollinearity problems because the results of multicollinearity tests showed tolerance values $>0.1$ and VIF values $<10$.

Table5. Heteroscedasticity Test Results

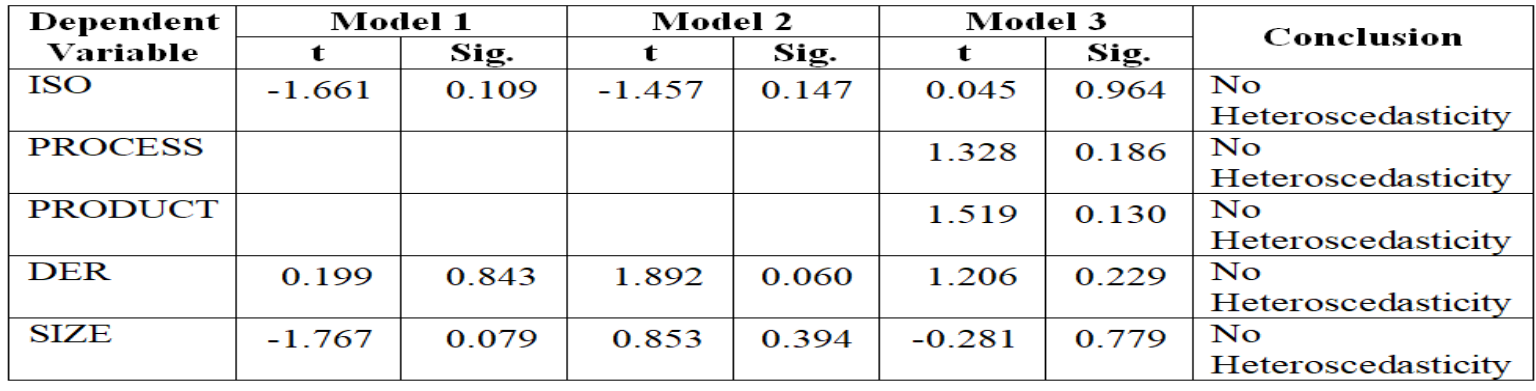

Source: processed data, 2018

Glejser test results in table 5 for regression model 1, regression model 2, and regression model 3 show the value of the probability of significance above the 5\% confidence level. These results show the regression model 1 , regression model 2 , and the regression model 3 in this study does not contain the symptoms of heteroscedasticity because the significance value is more than the $5 \%$ confidence level.

\subsection{Estimation of Path Analysis Results}

\subsubsection{Estimated Results of Model 1}

Model 1 of this study was conducted by multiple linear regression test which was conducted to examine the effect of environmental variables on the mediation variable. The results of multiple linear regression for model 1 are presented in table 6 below:

Table6. Results of Model 1 Multiple Linear Regression Analysis

\begin{tabular}{|c|l|l|l|l|l|l|}
\hline \multicolumn{2}{|c|}{ Model } & \multicolumn{2}{c|}{ Unstandardized Coefficients } & Standardized Coefficients & \multirow{2}{*}{ t } & \multirow{2}{*}{ Sig. } \\
\cline { 3 - 8 } & B & Std. Error & & & \\
\hline \multirow{2}{*}{1} & (Constant) & -.159 & .181 & & -.879 & .381 \\
\cline { 2 - 8 } & ISO & .041 & .019 & .172 & 2.125 & .035 \\
\cline { 2 - 7 } & DER & .005 & .008 & .042 & .584 & .560 \\
\cline { 2 - 8 } & SIZE & .010 & .015 & .054 & .644 & .520 \\
\hline
\end{tabular}

Source: processed data, 2018 
Based on the results contained in table 6 , the regression equation can be arranged as follows:

PROCESS = 0.172 ISO + 0.042 DER + 0.054 SIZE + e

\subsubsection{Estimated Results of Model 2}

Model 2 of this study was conducted by multiple linear regression test which was conducted to examine the effect of environmental variables on the mediation variable. The results of multiple linear regression model 2 are presented in table 7 below:

Table7. Results of Model 2 Multiple Linear Regression Analysis

\begin{tabular}{|l|l|l|l|l|l|l|}
\hline \multirow{2}{*}{ Model } & Unstandardized Coefficients & Standardized Coefficients & \multirow{2}{*}{ t } & \multirow{2}{*}{ Sig. } \\
\cline { 3 - 7 } \multicolumn{2}{|c|}{ B } & \multicolumn{1}{|c|}{ Btd. Error } & & & \\
\hline \multirow{3}{*}{1} & (Constant) & .012 & .160 & & .076 & .939 \\
\cline { 2 - 7 } & ISO & .011 & .017 & .054 & .658 & .511 \\
\cline { 2 - 7 } & DER & .005 & .007 & .046 & .622 & .534 \\
\cline { 2 - 7 } & SIZE & -.001 & .013 & -.007 & -.084 & .933 \\
\hline
\end{tabular}

Source: processed data, 2018

Based on the results contained in table 7, the regression equation can be arranged as follows:

\section{PRODUCT = 0.054 ISO + 0.046 DER - 0.007 SIZE + e}

\subsubsection{Estimated Results of Model 3}

Model 3 of this study was conducted using multiple linear regression tests to examine the effect of environmental commitment, green process innovation, and green product innovation on financial performance. Model 3 simple linear regression results are presented in table 8 below:

Table8. Results of Model 3 Multiple Linear Regression Analysis

\begin{tabular}{|l|l|l|l|l|l|l|}
\hline \multicolumn{2}{|c|}{ Model } & \multicolumn{2}{c|}{ Unstandardized Coefficients } & Standardized Coefficients & \multirow{2}{*}{ t } & \multirow{2}{*}{ Sig. } \\
\cline { 3 - 8 } & \multicolumn{1}{|c|}{ B } & Std. Error & & & \\
\hline \multirow{2}{*}{1} & (Constant) & -.286 & .142 & & -2.008 & .046 \\
\cline { 2 - 7 } & PROCESS & .270 & .056 & .303 & 4.824 & .000 \\
\cline { 2 - 7 } & PRODUCT & .133 & .063 & .130 & 2.115 & .036 \\
\cline { 2 - 7 } & ISO & .035 & .015 & .165 & 2.283 & .023 \\
\cline { 2 - 7 } & DER & -.025 & .007 & -.248 & -3.873 & .000 \\
\cline { 2 - 7 } & SIZE & .028 & .012 & .175 & 2.372 & .019 \\
\hline
\end{tabular}

Source: processed data, 2018

Based on the results contained in table 8 , the regression equation can be arranged as follows:

ROE = 0.303 PROCESS + 0.130 PRODUCT + 0.165 ISO - 0.248 DER + 0.175 SIZE + e

\section{HyPOTHESIS TEST RESULTS AND DISCUSSION}

\subsection{Effect of Environmental Commitment on Financial Performance}

The results of the statistical tests in this study indicate that environmental commitment has a positive effect and proved significant to financial performance so that hypothesis 1 (H1) is accepted. This is consistent with research conducted by Cui et al. (2015), Yahya and Ha (2013), Azorin (2009), Benito and Benito (2005), Menguc and Ozanne (2005), and Lee and Miller (1999) that environmental commitment has a positive effect and is proven to be significant in financial performance.

The results of this study reject the results of research conducted by Aznar et al. (2016). Environmental commitment in the company does not show a significant relationship with the company's performance due to a lack of proactive consumer attitudes so that the differentiation of companies with environmental commitments will not result in better financial performance. The results of this study also rejected the results of Cui et al. (2015) which shows a negative relationship between commitment to environmental issues and profitability because the commitment makes a burden on small companies.

\subsection{Effect of Environmental Commitment on Green Process Innovation}

The results of the statistical tests in this study indicate that environmental commitment has a positive and significant effect on green process innovation so hypothesis 2 (H2) is accepted. The research 
conducted by Atmosphere and Ekawati (2018) shows the results that the higher the company's commitment to safeguarding the environment in its business activities, the better the application of green process innovation. This is supported by research conducted by Burki and Dahlstrom (2017) and Chang and Chen (2013) which provide empirical evidence that environmental commitment has a positive effect and has proven significant towards green process innovation.

The results of this study reject the results of research conducted by Caracuel and Mandojana (2013) explaining that environmental innovation is not running optimally because of knowledge gaps, unwillingness to take risks in the capital market, and inadequate government support. The existence of environmental commitments carried out through an environmentally friendly innovation process (green process innovation) cannot run optimally in the company.

\subsection{Effect of Environmental Commitment on Green Product Innovation}

Subsequent statistical test results in this study indicate that environmental commitment has a positive but not significant effect on green product innovation so hypothesis $3(\mathrm{H} 3)$ is rejected. Grekova et al. (2013) explained that additional skills and knowledge are needed in innovation because of the high complexity of innovation related to the environment compared to other innovations. Especially green product innovation is considered more complex than green process innovation. Therefore, innovation in products cannot be performed optimally through a commitment because green product innovation is considered more complex than green process innovation for companies.

According to Cui et al. (2015), the existence of environmental commitment makes the burden on companies, especially in developing countries. Thus, ownership of ISO 14001 certification in the company as a form of environmental commitment cannot influence the company to innovate environmentally friendly products. This is in accordance with the research conducted by Wagner (2008) Environmental commitment has no significant effect on green product innovation.

The results of this study reject the results of research conducted by Kassar and Singh (2018), Atmosphere and Ekawati (2018), and Chang and Chen (2013) where companies with a high commitment to the environment influence the achievement of green process innovation in the company.

\subsection{The Effect of Green Process Innovation on Financial Performance}

The results of the statistical tests in this study indicate that green process innovation has a positive effect and is proven to be significant towards financial performance so that hypothesis $4(\mathrm{H} 4)$ is accepted. Research conducted by Alhadid and Rumman (2014) and Chang and Chen (2013) which provide empirical evidence that green process innovation has a significant positive effect on financial performance.

The production process is redesigned to reduce energy and water use, replace conventional energy sources with the latest energy more efficiently, and prevent water, soil and air pollution (Grekova et al., 2013). This improvement has the potential to reduce operational costs, save waste management costs, and increase productivity and efficiency so that an increase in profits is followed by an increase in the company's financial performance.

The results of this study reject the results of research conducted by Chang (2011) and Gunday et al. (2011) provide empirical evidence that companies that do innovation do not directly benefit the company. This is because in the innovation process requires the development of knowledge and technology that requires a large cost in carrying it out. Large costs have an impact on the decline in the company's performance in the short term, due to the large costs incurred for new technology.

\subsection{Effect of Green Product Innovation on Financial Performance}

The results of the subsequent statistical tests in this study indicate that green product innovation has a positive effect and is proven to be significant towards financial performance so that hypothesis 5 (H5) is accepted. The results of this study are consistent with research conducted by Ar (2012), Alhadid and Rumman (2014) and Chang and Chen (2013) which provide empirical evidence that green product innovation has a significant positive effect on financial performance

Products are designed to minimize environmental impacts during the life cycle of these products, such as avoiding the use of raw materials containing chemicals and toxins and minimizing the use of 
product resources so as to create efficiency in the allocation of operational costs that can improve financial performance. In addition, the results of the new products and products that have been developed do not have many competitors so the company can determine the high price level of new products resulting from these innovations because there are no competitors who can provide low prices on similar products so that green product innovation can increase company financial performance.

The results of this study reject the results of research conducted by Caracuel and Mandojana (2013) explaining that green innovation does not run optimally because of knowledge gaps, unwillingness to take risks in the capital market, and inadequate government support. In addition, the results of Fitriani's (2017) research also provide results that green product innovation does not have a significant positive effect on financial performance.

\subsection{Effect of Environmental Commitment on Financial Performance through Green Process Innovation}

The results of the Sobel Test and mediation requirements by Baron and Kenny (1986) show that green process innovation is able to be a link between the influence of environmental commitment on financial performance so that hypothesis $6(\mathrm{H} 6)$ is accepted. The application of green process innovation can mediate the influence of ISO 14001 on the company's financial performance. Research conducted by Grekova et al. (2018) and Ryszko (2016) provide empirical evidence of a significant positive influence on green process innovation in mediating the relationship between ISO 14001 and company performance.

The existence of ISO owned by the company shows that the company has fulfilled its commitment to the environment so that the company has fulfilled the legitimacy of the community. The fulfillment of this legitimacy makes it easier for companies to get support from stakeholders so that the application of green innovation is more optimal. Implementation of green process innovation will reduce operational costs, reduce waste management costs, and increase productivity and efficiency so that an increase in profits is followed by an increase in the company's financial performance.

\subsection{Effect of Environmental Commitment on Financial Performance through Green Product Innovation}

The results of the Sobel Test and mediation requirements by Baron and Kenny (1986) show that green product innovation is not able to be a link between the influence of environmental commitment on financial performance so that hypothesis 7 (H7) is rejected. This is consistent with research conducted by Grekova et al. (2013) and Aznar et al. (2016) where green product innovation is not able to be a link between the influence of environmental commitment on financial performance, explaining that additional skills and knowledge are needed to innovate because of the high complexity of green product innovation rather than other innovations.

Fitriani (2017) provides empirical evidence that the application of green product innovation by the company cannot be directly felt by the company because it requires a long time so that innovation can be useful for improving the company's financial performance. Therefore, green product innovation does not succeed in mediating the influence of environmental commitment on financial performance. The results of this study reject the results of research conducted by Ryszko (2016) and Burki and Dahlstrom (2017) which show that green product innovation successfully mediates the influence of environmental commitment on financial performance.

\section{CONCLUSION}

The conclusions obtained from the results of the study are the application of environmental commitments carried out through ISO 14001 certification can improve the company's financial performance as measured by return on equity (ROE) through the existence of green process innovation by the company. However, the application of environmental commitment cannot improve financial performance through the existence of green product innovation. Environmental innovation through green product innovation has not been fully implemented optimally in the company. The company's efforts to innovate the environment are still limited to innovation in the production process. Innovation in the production process is carried out to create efficient use of energy and resources that have an impact on reducing costs during the production process. 


\section{REFERENCES}

[1] Agustina, R. D., \& Fauzi, D. 2016. Pengaruh Pemasaran Hijau Terhadap Citra Merek Hijau Serta Dampaknya Pada Keputusan Pembelian (Survei pada Mahasiswa Jurusan Administrasi Bisnis Strata-1 Angkatan 2012/2013 dan 2013/2014 Fakultas Ilmu Administrasi Universitas Brawijaya yang Menggunakan Tis. Jurnal Administrasi Bisnis, Vol. 33(1): 171-179.

[2] Alhadid, A. Y., \& Rumman, A. a. A. 2014. The Impact of green innovation on organizational performance, environmental management behavior as a moderate variable: An analytical study on Nuqul group in Jordan. International Journal of Business and Management, Vol. 9(7): 51.

[3] Ar, I. M. 2012. The impact of green product innovation on firm performance and competitive capability: the moderating role of managerial environmental concern. Procedia-Social and Behavioral Sciences, Vol. 62: 854-864.

[4] Ardyan, E., Nurtantiono, A., Istiyanto, B., \& Rahmawan, G. 2017. Green Innovation Capability As Driver Of Sustainable Competitive Advantages And Smes Marketing Performance Technology, Vol. 8(8): 11141122.

[5] Atmawinata, A. 2012. Pendalaman Struktur Industri : Efisiensi Dan Efektivitas Dalam Implementasi Industri Hijau Diakses tanggal, 20 Desember 2017, dari http://www.kemenperin.go.id/download/6297/ Efisiensi-dan-Efektivitas-dalam-Implementasi-Industri-Hijau

[6] Aziza, N. 2014. Anteseden Pengungkapan Lingkungan dan Pengaruh Nyata Terhadap Image Perusahaan. Fairness, Vol. 4(1): 1-21.

[7] Aznar, J. P., Sayeras, J. M., Galiana, J., \& Rocafort, A. 2016. Sustainability Commitment, New Competitors' Presence, and Hotel Performance: The Hotel Industry in Barcelona. Sustainability, Vol. 8(8): 755.

[8] Azorín, J. F. M., Claver-Cortés, E., Pereira-Moliner, J., \& Tarí, J. J. 2009. Environmental practices and firm performance: an empirical analysis in the Spanish hotel industry. Journal of Cleaner Production, Vol. 17(5): 516-524.

[9] Baker, W. E., \& Sinkula, J. M. 2005. Environmental marketing strategy and firm performance: Effects on new product performance and market share. Journal of the academy of marketing science, Vol. 33(4): 461.

[10] Benito, J. G., \& Benito, Ó. G. 2005. Environmental proactivity and business performance: an empirical analysis. Omega, Vol. 33(1): 1-15.

[11] Burki, U., \& Dahlstrom, R. 2017. Mediating effects of green innovations on interfirm cooperation. Australasian Marketing Journal (AMJ), Vol. 25(2): 149-156.

[12] Caracuel, J. A., \& Mandojana, N. O. d. 2013. Green innovation and financial performance: An institutional approach. Organization \& Environment, Vol. 26(4): 365-385.

[13] Chang, C.-H., \& Chen, Y.-S. 2013. Green organizational identity and green innovation. Management Decision, Vol. 51(5): 1056-1070.

[14] Chen, Y.-S., Chang, C.-H., \& Wu, F.-S. 2012. Origins of green innovations: the differences between proactive and reactive green innovations. Management Decision, Vol. 50(3): 368-398.

[15] Chen, Y.-S., Lai, S.-B., \& Wen, C.-T. 2006. The influence of green innovation performance on corporate advantage in Taiwan. Journal of business ethics, Vol. 67(4): 331-339.

[16] Cui, Z., Liang, X., \& Lu, X. 2015. Prize or price? Corporate social responsibility commitment and sales performance in the Chinese private sector. Management and Organization Review, Vol. 11(1): 25-44.

[17] Deegan, C. 2002. Introduction: The legitimising effect of social and environmental disclosures-a theoretical foundation. Accounting, Auditing \& Accountability Journal, Vol. 15(3): 282-311.

[18] DiMaggio, P. J., \& Powell, W. W. 1983. The iron cage revisited institutional isomorphism and collective rationality in organizational fields. American Sociological Review, Vol. 48(2): 147-160.

[19] Dowling, J., \& Pfeffer, J. 1975. Organizational legitimacy: Social values and organizational behavior. Pacific sociological review, Vol. 18(1): 122-136.

[20] Fitriani, L. K. 2017. Analisis Green Inovation Dampaknya Terhadap Keunggulan Bersaing Produk Dan Kinerja Pemasaran (Studi Empirik Pada Ukm Batik Ciwaringin Kabupaten Cirebon). Journal of Management and Business Review, Vol. 12(2).

[21] Grekova, K., Bremmers, H., Trienekens, J., Kemp, R., \& Omta, S. 2013. The mediating role of environmental innovation in the relationship between environmental management and firm performance in a multi-stakeholder environment. Journal on Chain and Network Science, Vol. 13(2): 119-137.

[22] Hart, S. L. 1995. A natural-resource-based view of the firm. Academy of management review, Vol. 20(4): 986-1014. 
[23] Henriques, I., \& Sadorsky, P. 1999. The relationship between environmental commitment and managerial perceptions of stakeholder importance. Academy of management Journal, Vol. 42(1): 87-99.

[24] Indonesia, R. 2002. Undang-Undang Republik Indonesia Nomor 18 Tahun 2002 tentang Sistem Nasional Penelitian, Pengembangan, dan Penerapan Ilmu Pengetahuan dan Teknologi. Jakarta.

[25] ISO. 2015. Introduction to ISO 14001:2015 Diakses tanggal, dari https://www.iso.org/files/live/sites/ isoorg/files/archive/pdf/en/introduction_to_iso_14001.pdf

[26] Kassar, A.-N., \& Singh, S. K. 2018. Green innovation and organizational performance: the influence of big data and the moderating role of management commitment and HR practices. Technological Forecasting and Social Change.

[27] Kemp, R., \& Arundel, A. 1998. Survey indicators for environmental innovation.

[28] Keogh, P. D., \& Polonsky, M. J. 1998. Environmental commitment: a basis for environmental entrepreneurship? Journal of organizational change management, Vol. 11(1): 38-49.

[29] Kucukoglu, M. T., \& Pınar, R. İ. 2015. The Mediating Role Of Green Organizational Culture Between Sustainability And Green Innovation: A Research In Turkish Companies. Business \& Management Studies: An International Journal, Vol. 6(1).

[30] Lazonick, W., \& Prencipe, A. 2005. Dynamic capabilities and sustained innovation: strategic control and financial commitment at Rolls-Royce plc. Industrial and Corporate Change, Vol. 14(3): 501-542.

[31] Lee, J., \& Miller, D. 1999. People matter: Commitment to employees, strategy and performance in Korean firms. strategic management journal, Vol. 20(6): 579-593.

[32] Li, Y. 2014. Environmental innovation practices and performance: moderating effect of resource commitment. Journal of Cleaner Production, Vol. 66: 450-458.

[33] Menguc, B., \& Ozanne, L. K. 2005. Challenges of the "green imperative": A natural resource-based approach to the environmental orientation-business performance relationship. Journal of Business Research, Vol. 58(4): 430-438.

[34] Miroshnychenko, I., Barontini, R., \& Testa, F. 2017. Green practices and financial performance: a global outlook. Journal of Cleaner Production, Vol. 147: 340-351.

[35] Munandar, H. 2017. Inovasi Teknologi Untuk Mewujudkan Industri Hijau. Kementrian Perindustrian Republik Indonesia Diakses tanggal, 20 Desember 2017, dari http://sntih.kemenperin.go.id/service.php? pos $=$ download $\&$ mode $=$ hal $\& \mathrm{fl}=$ unduh $\&$ file $=1037$.

[36] Nastiti, R. 2004. Environmental Commitment: Faktor Fundamental pada Environmental Entrepreneurship. Jurnal Manajemen Maranatha, Vol. 4(1).

[37] Nishitani, K. 2009. An empirical study of the initial adoption of ISO 14001 in Japanese manufacturing firms. Ecological Economics, Vol. 68(3): 669-679.

[38] Nugroho, B. 2010. Pembangunan kelembagaan pinjaman dana bergulir hutan rakyat. Jurnal Manajemen Hutan Tropika, Vol. 16(3): 118-125.

[39] Ozzie, L., \& Malelak, M. I. 2015. Pengaruh Corporate Culture dan Organisational Commitment terhadap Financial Performance Perusahaan Keuangan di Surabaya. Finesta, Vol. 3(1): 79-84.

[40] Peters, B. 2005. The Relationship between Product and Process Innovations and Firm Performance: Microeconometric Evidence.

[41] Richey, G., Genchev, S. E., \& Daugherty, P. J. 2005. The role of resource commitment and innovation in reverse logistics performance. International Journal of Physical Distribution \& Logistics Management, Vol. 35(4): 233-257.

[42] Ryszko, A. 2016. Proactive environmental strategy, technological eco-innovation and firm performanceCase of poland. Sustainability, Vol. 8(2): 156.

[43] Suasana, I. G. A. K. G., \& Ekawati, N. W. 2018. Environmental commitment and green innovation reaching success new products of creative industry in Bali. Journal of Business and Retail Management Research Vol. 12 (4).

[44] Sudana, I. M. 2009. Manajemen Keuangan Teori dan Praktik. Surabay: Airlangga University Press.

[45] Sudaryati, E., \& Amelia, F. 2015. Analisis perbandingan kinerja keuangan perusahaan prospector dan defender (studi pada perusahaan manufaktur yang terdaftar di bursa efek indonesia periode tahun 20102012). (JRAMB) Jurnal Riset Akuntansi Mercu Buana, Vol. 1(2).

[46] Tang, M., Walsh, G., Lerner, D., Fitza, M. A., \& Li, Q. 2018. Green Innovation, Managerial Concern and Firm Performance: An Empirical Study. Business Strategy and the Environment, Vol. 27(1): 39-51.

[47] Wagner, M. 2008. Empirical influence of environmental management on innovation: evidence from Europe. Ecological Economics, Vol. 66(2-3): 392-402. 
[48] Waters, J. 2000. Achieving innovation or the Holy Grail: managing knowledge or managing commitment? International Journal of Technology Management, Vol. 20(5-8): 819-838.

[49] Yahya, W. K., \& Ha, N. C. 2013. The Relationship Between Environmental Issues And Organisational Performance. International Journal of Business \& Society, Vol. 14(1).

\section{AUTHORS' BIOGRAPHY}

Movie Rahmatika Suryani earned her Bachelor's Degree from Faculty of Economic and Business, Airlangga University for Accounting Major in 2015 and later her Master's Degree from Faculty of Economic and Business, Airlangga University from Accounting Major in 2018.

Wiwiek Dianawati earned her Bachelor's Degree from Faculty of Economic and Business, Airlangga University for Accounting Major in 1985, her Master's Degree from Faculty of Economic and Business, Airlangga University for Management Science Major in 2000 and later her Doctor's Degree from Faculty of Economic and Business, Airlangga University for Accounting Major in 2015. Currently she is a lecturer at Airlangga University.

Citation: Movie Rahmatika Suryani, Wiwiek Dianawati. "The Effect of Environmental Commitment on Financial Performance through Green Innovation". International Journal of Managerial Studies and Research (IJMSR), vol 6, no. 11, 2018, pp. 30-42. doi: http://dx.doi.org/10.20431/2349-0349.0611003.

Copyright: () 2018 Authors. This is an open-access article distributed under the terms of the Creative Commons Attribution License, which permits unrestricted use, distribution, and reproduction in any medium, provided the original author and source are credited. 